\title{
Brave New Teachers: Doing Social Justice Work in Neo-liberal Times
}

Patrick Solomon, Jordan Singer, Arlene Campbell, Andrew Allen, and with the assistance of John Portelli. Toronto: CSPI, 2011, pp. 315. ISBN 978-1-55130-397-0 (pbk.)

Barbara Anne Pollard

University Of Windsor

\begin{abstract}
The authors of Brave New Teachers adopt a critical-democratic lens to analyze how neoliberal educational agendas have impacted the ability of progressive teachers to cultivate equitable and inclusive classrooms. The book is based on a longitudinal study that documents the self-reported teaching experiences of a group of teachers who graduated from the Urban Diversity Program at York University. Brave New Teachers explores how the current context of Canadian schooling has been shaped by neoliberalism. Within this paradigm, the authors thematically emphasize how standardized testing and the accountability movement, as well as the top-down imposition of curriculum standards, circumscribe the efforts of courageous teachers who work diligently on creating anti-oppressive curriculums and school environments. The tension that exists when these teachers feel pressured to conform to higher top-down authorities is documented throughout the book.
\end{abstract}

As a beginning scholar studying the political and social contexts of education, it seems imperative to critically examine the detrimental outcomes of neoliberalism, most notably, the marketization of education. Brave New Teachers: Doing Social Justice Work in Neo-liberal Times, is especially productive in this regard. The book thematically illuminates the negative effects of neoliberal driven educational reforms, by discussing the contradictions and tensions experienced by critical and democratic teachers who value and engage in equity focused and anti-oppressive teaching practices. After reading Brave New Teachers, one can more fully appreciate the difficult and complicated work undertaken by teachers working for change. These teachers often struggled with their commitment to facilitating critical and democratic teaching approaches as they are positioned in the center of neoliberal structured educational systems. The teaching experiences conveyed exemplify, again and again, that we still have a long way to go in terms of creating equitable and inclusive teaching environments. The reader is left with the resonating idea that resistance, rather than conformity, to traditional teaching approaches and neoliberal generated educational reform, is key to transformative practices that foster equity, justice, and liberation within classrooms.

The book is organized into seven chapters all contributed by coauthors, Patrick Solomon, Jordan Singer, Arlene Campbell, and Andrew Allen with the assistance of John Portelli. The authors utilized a critical-democratic theoretical framework for analysis that emphasized how neoliberal educational agendas circumscribe issues of equity, diversity and social justice. Each chapter drew from a three-year qualitative study that documents the lived teaching experiences of 42 culturally diverse student teachers of whom graduated from the Urban Diversity Program within the Faculty of Education, at York University. Brave New Teachers explores several aspects of the central question within the study: "Given the current climate of schooling in Western democracies such as Canada and the top-down imposition of curriculum standards, do teachers acquiesce to this higher authority, compromise their democratic principles to avoid conflict and confrontation, or negotiate space to practice equity and diversity in their pedagogy?” (p. 22). For example, Chapter Four, entitled Identity Matters when Teaching for Equity, written by scholar Andrew Allen, presents insightful narratives that reveal how urban education teachers come to realize that their social identity (e.g., interaction of 
race, class, gender, and sexual orientation) is interweaved with their world-views and consequently, significantly shapes their teaching practices. To this extent, Allen's chapter offers several rich, critically constructed, and nuanced teacher reflections that reveal the multi-layered systemic racism that is persistent in schools. For example, one urban education teacher expressed, "It was interesting because in some schools in which I supplied, I literally had teachers craning their necks to see who was this person of colour in their school" (p. 177). Taboo topics, such as White Privilege, and the lived tensions experienced by minority teachers when their race is positioned as other, provide the reader with new threshold knowledges for examining issues of social identity and its implications. The authors consistently emphasize, as exemplified by the participants in the study, that these types of critical analyses can productively influence the construction of equitable and inclusive teaching practices.

The strength of Brave New Teachers lies in its ability to effectively present the reader with ways to counter neoliberal educational reforms by offering alternate educational landscapes that are founded on equitable and inclusive teaching practices which value democracy. In order to begin this journey, the authors argue that both novice and experienced teachers must seriously question: 1.) Who was the curriculum designed for, 2.) who are we teaching for, and 3.) what are we teaching for? In the process of continuously reflecting on these important questions, as the urban diversity teachers have done and continue to do, the authors passionately assert that teachers can become critical reflective practitioners that empower children in emancipatory educational experiences, despite the standardization and accountability educational reforms that contradict these efforts. One of the key steps in this process, which is done repeatedly by the urban diversity teachers, is a type of self-study which directs teachers to critically reflect on who they are and how this particular way of being and knowing impacts their teaching practices. Ultimately, and most importantly, the authors conclude that teachers must then assess how their dialogical relationship with students impacts student learning, motivation, and academic achievement. For instance, Brave New Teachers emphasizes that, after much reflection, most of the teachers within the study have concluded that the curriculum is overwhelming dense and is too narrowly focused on discrete bits of knowledge. Consequently, many teachers felt that in order to meet the overwhelming content expectations, they would have to utilize very rigid and limited instructional approaches. One student teacher reflected, "I find the curriculum wants you to do a million things-not necessarily very well-so there is not enough room to have student engagement in there. Social and critical engagement about a subject, combined with inclusive education and critical thinking, takes time. I think that's the frustration I have: How do I take the complex things and fit it into 25 expectations?" (p. 79). The idea that what teachers do matters a great deal in terms of student achievement, may sound like an obvious and straight forward statement. However, as repeatedly illustrated by the urban diversity teachers within Brave New Teachers, constructing a teaching practice that is equity focused and anti-oppressive, while immersed in the paradigm of mandated curriculums and standardized testing, is a paramount, complex, and noble task that requires continuous effort and perseverance.

The general sense gleaned from reading Brave New Teachers is that most of the urban diversity teachers felt compelled to problematize our current neoliberal-driven educational system. In the doing, they negotiated their day-to-day and long term teaching philosophies and practices in order to accommodate equity based instructional approaches. As one student explains, "I found a way to include equity and diversity because I had to. It's who I am; it's who my students are, and I wouldn't be an effective teacher if I didn't find a way to include equity" (p. 111). After reading the book, one can clearly understand that in not striving for an alternative educational teaching practice, that is founded on principles of equity, diversity social justice, the children and their lived experiences continue to be irrelevant and disconnected from the learning process. Consequently, the platform for cultivating a critical lens is removed as downloading bits of discrete knowledge from the 
curriculum becomes the priority. In acknowledging this problematic reality, one urban diversity teacher emphasizes, "Just remember that it's the kids we are teaching, not the curriculum" (p. 60). As a researcher who works toward putting equity focused teaching theories into practice, and a strong proponent of critical reflection, I especially gravitated to these kinds of thought provoking and insightful teacher reflections interweaved throughout the book. Overall, a very worthwhile read, that offers novice and experienced educators, scholars, administrators, and policy makers, hope for creating just and equitable educational learning environments that are both liberating and engaging all at once.

\section{References}

Solomon, R. P., Singer, J., Campbell, A., Allen, A., \& Portelli, P. (2011). Brave new teachers: Doing social justice work in neoliberal times. Toronto, ON: Canadian Scholars' Press. 